\title{
MEZI RACIONALISMEM A JUDAISMEM: FILOSOFICKÁ SEBEREFLEXe RAYMONDA ARONA
}

Jiři Nesiba \& Josef Smolík*

\section{Between Rationalism and Judaism: Raymond Aron's Philosophical Self-reflection}

\begin{abstract}
The paper analyses the work of French philosopher Raymond Aron from the perspective of how he was influenced by his personal experience with anti-Semitism and how it changed his description of Judaism. The article focuses on the fact that Aron preferred a methodological approach instead of actual emotions as a member of the assimilated Jewish minority in France. The paper notes Aron's commentary about changes in society regarding the Jewish minority in the time after the Dreyfus Affair in France, during Nazism, after the establishment of the state of Israel, during the Six-Day War, or from the 1970 s on with the emergence of the Palestinian problem and the rise of right-wing politics in Israel. The authors proceeded by analyzing Aron's academic and journalistic texts chronologically as they were published during his life or after his death. The authors show the consistency in Aron's thinking. The authors investigate the extent to which these political events transformed Aron's thinking and how he copes with his own philosophical self-reflection on Judaism, demanding strict scientific objectivity on the one hand and understanding religious tradition on the other. The Presented analysis describes how Aron in the social sciences preferred methodologies before the analysis itself. He implemented this approach in his studies and articles that analyzed Judaism, for which he felt a personal emotional sentiment.
\end{abstract}

Key words: Raymond Aron, anti-Semitism, Judaism, Israel, rationalism.

DOI: https://doi.org/10.24132/actaff.2018.10.1.2

*PhDr. Jiří Nesiba, Ph.D., Ústav sociálního rozvoje, Fakulta regionálního rozvoje a mezinárodních studií, Mendelova univerzita v Brně, jiri.nesiba@mendelu.cz, PhDr. Mgr. Josef Smolík, Ph.D., MBA, LL.M., Ústav sociálního rozvoje, Fakulta regionálního rozvoje a mezinárodních studií, Mendelova univerzita v Brně, josef.smolik@mendelu.cz. 


\section{1. ÚVOD}

Francouzský filosof Raymond Aron (1905-1983) byl známý tím, že vystupoval do veřejného prostoru nejen jako sociolog a historik, ale také jako novinář. Snažil se uplatňovat metodu popisu tzv. „dějin přitomnosti“ (fr. l'histoire du présent) či jako aktuální historie (fr. l'histoire immédiate). Vedl díky tomu břitké polemiky v době studené války proti ideologickému myšlení. Jako účastník protinacistického zahraničního odboje, i jako podporovatel prezidenta de Gaulla tvrdil, že argumentace ideologií manipulují člověka ve prospěch manipulativní filosofie, kterou lze rozpoznat pomocí racionálního přístupu. Politika pak dokáže využít ideologie a vynutit si jednání v rozporu se zájmy jednajícího, což se projevuje např. v mezinárodních vztazích (Aron 1962a: 102).

V kontextu tohoto známého Aronova postoje k ideologiím je často opomíjený fakt, že sám pocházel z židovské asimilované rodiny, kdy na vlastní kůži vnímal antisemitské nálady ve Francii, ale i v Německu. V příspěvku zkoumáme, jak se Aron ve svém díle se svým rodinným původem vyrovnával, a jakým způsobem ho to ovlivňovalo při sociologických analýzách moderní společnost a mezinárodních vztahů, a to zejména vzhledem k izraelské politice. Na první pohled se zdá, že se Aronův postoj $\mathrm{k}$ této problematice měnil. V 50. letech projevoval nedůvěru k sionismu jako levicovému hnutí, poté vyjadřoval solidaritu $\mathrm{k}$ obranné válce Izraele v 60. letech a na závěr života jako novinář projevoval kritiku ke stylu pravicové izraelské politiky. Nicméně, jak článek dokládá, Aron se držel po celou dobu stejného racionálního nadhledu při diagnostice politického či sociálního rozboru. Aronovy názory na toto téma oscilovaly mezi nestranným sociologickým vědeckým př́stupem ke zkoumání náboženství jako součásti sociálních vazeb ve společnosti a jeho sentimentem k židovství a Izraeli. Neznamená to, že by rezignoval na nestranný rozbor. Dokázal mít odstup od všech ideologií, nejen politické - nacionální či komunistické, ale kterou s sebou nese také judaismus či izraelská politika. Aron své nadání pro filosofické hodnocení historických i aktuálních politických témat uplatňoval v důsledném zdůrazňování práce $\mathrm{s}$ fakty, a nikoliv úvahami. V článku jde o představení dynamiky Aronova myšlení, a zároveň ukázání, jak udržel racionální metodiku analýzy i pro emotivní témata spojená s jeho osobní zkušeností s antisemitismem a obecně ideologií, které stojí na omezení práv menšin.

Aron bývá někdy nazýván „aristokratem inteligence“ (Lettere 2005). Ve své době se dokonce ve Francii vžilo označení „aronovsky jasný“ (Dahrendorf 2008). Tento jeho nestranný přístup vyplýval i z osobních zkušeností příslušníka židovské menšiny ve Francii, která díky tradici vnímala majoritní názory z určitého odstupu. Nedůvěřivý postoj vůči názoru většiny Aron získal díky svým životním zkušenostem v předválečném období, ale i v době studené války, kdy pocítil vlivy nejrůznějších demagogií a ideologií, které se snažily vést veřejnost $\mathrm{k}$ zneužívání moci ve prospěch totalitních režimů či diktatur. To dlouhodobě potvrzoval nejen svými vědeckými a novinářskými pracemi, ale i osobním životem (srov. Colquhoun 1986; Baverez 1986). 


\section{KRITIKA IDEOLOGIÍ}

Aron se inspiroval weberovskou metodiku tzv. ideálních typů. Dle této metodiky vytvořil koncept a podle něj poměřoval aktuální politickou situaci. Proto k pochopení jeho vztahu $\mathrm{k}$ analýze politiky skrze židovství je třeba nejdříve vysvětlit obecně jeho postoj k ideologickému a demokratickému systému. Tyto dva politické systémy považoval za opačné ideální typy (styly) politiky 20. století. Dle takového prizmatu posuzoval judaismus i politiku státu Izrael či blízkovýchodní konflikt. Izrael již od svého vzniku považoval jako ostrov západní demokracie na Blízkém východě, který pomůže celému regionu. Vycházel při tom ze svého přesvědčení liberála a demokrata, který kritizuje jakékoliv tendence ideologického myšlení, jehož stopy nacházel už $\mathrm{v}$ úmyslně přizpůsobené interpretaci dějin, které měly sloužit k ospravedlnění nějaké konkrétní politiky (Nesiba 2010).

Aron velkou část svých studií věnoval světovým konfliktům. Při konfliktu se odhaluje ideologie nejplastičtěji. Ideologie je záležitostí politiky v době míru, v době konfliktu se ukazuje realistická stránka politiky, protože vítěz bere vše. Většina Aronových mezinárodněpolitických studií proto nese v názvu tématiku moci, války či konfliktů, např. L'Âge des Empires et l ávenir de la France, čes. Věk impérii a budoucnost Francie (Aron 1945); Les Guerres en chaînes, čes. Války v řetězech (viz Aron 1951); Espoir et peur du siècle. Essaie non partisans, čes. Naděje a strach století. Nestranné eseje (Aron 1956a); La Société industrielle et la Guerre, čes. Industriální společnost a válka (srov. Aron 1959); Paix et guerre entre les nations, čes. Mír a válka mezi národy (blíže viz Aron 1962a) nebo Penser la guerre, Clausewitz, čes. Uvažovat válku (srov. Aron 1976).

Aron se nejdřive na existenci Izraele díval s určitou nedůvěrou, především kvůli levicovým sionistickým vlivům hledajícím inspiraci v ideologiích, jako byl bolševismus a komunismus. Naopak od šedesátých let, kdy hrozilo Izraeli zničení ze strany okolních arabských států, se stal obhájcem práva Izraele na obranu. V té době Aron ukazoval, jak důležitá je existence Izraele pro rovnováhu ve studené válce. Se začátkem okupace palestinských území izraelskou armádou po šestidenní válce v roce 1967 se naopak stal postupně kritikem izraelské pravicové politiky, která podlehla zjednodušenému názoru o izraelské vojenské a ekonomické neporazitelnosti od okolních arabských států. Tyto jeho postřehy s nárůstem terorismu se ukázaly jako přesné. Ke sklonku života proto lze pozorovat dvě tendence v jeho myšlení - jednak sympatie k samotnému státu Izrael, jednak nesouhlas s jeho pravicovou politikou. Ve svých úvahách striktně odděloval tradici judaismu a politiku židovského státu. Proto tvrdil, že dějiny Izraele lze zkoumat objektivně velmi obtížně. Sám přiznával, že ani on v určitých souvislostech nemůže kvưli svému židovskému původu být poctivě objektivní (Aron 1976: 1319-1354).

Aron odmítal jakoukoliv formu historicismu a determinismu (což je při debatách o Blízkém východě jeden z nejčastěji používaných argumentů, kdo má právo tuto oblast obývat, zda Židé či Palestinci), aby neupadl do pasti naivního idealismu, který s sebou nese černobílé hodnotové soudy. Podle něj jako liberála je člověk svobodný, ale je ve svém jednání omezen sociální, politickou a ekonomickou realitou. Poznání těchto omezení je úkolem historika, poznat svobodu jedince je úkolem filosofa (Aron 1976, 206-242). 
Aron byl výrazně ovlivněn myšlením Charlese Montesquieho, Alexise de Tocqueville, Immanuela Kanta či Maxe Webera. Tito filosofové jej inspirovali ve snaze o objektivní přístup $\mathrm{k}$ popisu politiky, bez předsudků a dogmat, nestranit žádné straně konfliktu. Byl proto pro svůj přístup považován za přísného realistu, za machiavelistu, nebo přinejmenším pesimistu (Meuwly 2005). Na rozdíl od množství svých oponentů zachovával odstup od jednoduchých a jednoznačných vysvětlení, věrný filosofické stoické tradici zdržení se jednoznačného úsudku, který měl ve francouzském prostředí tradici už od dob René Descarta a nesl označení epoché.

Raymond Aron se označil v titulu jedné ze svých posledních knih jako „,angažovaný pozorovatel" a toto jeho označení nemohlo být přesnější (Aron 1981; 2003b). Výsledkem jeho analýz byl celkový obraz daného problému, ale také odhalování polopravd, mýtů a zjednodušených názorů, které bývaly zneužívány k ideologicky zabarveným argumentům sloužícím politickým cílům. Jeho životní zkušenost jej spíše formovala takovým způsobem, že každá událost byla podle něj ovlivněna momentální situací, což jej vedlo k přesvědčení, že obecné univerzální zákony v politice či historii neexistují. Aron svými analýzami odhaloval, jak se za zdánlivě jednoznačnými názory může skrývat množství protichůdných pohledů (Bruckberger 1987).

Právě díky své metodice se stal kritikem ideologických konceptů své doby, tedy fašismu a komunismu. Ve francouzském prostředí byl v poválečné době levicovými intelektuály vnímán jako intelektuál ospravedlňující svými analýzami pravicový gaullistický styl politiky. Jean-Paul Sartre ho v šedesátých letech označil za intelektuála, který „nepřekročí myšlenkový horizont vládnoucí třídy“. Obecně byl kritický pohled levicové generace šedesátých let na Arona po dlouhou dobu určujícím pohledem na celý jeho intelektuální odkaz (Sirinelli 1995).

Generace poválečných intelektuálů ve Francii byla silně ovlivněná marxismem. V umírněné podobě tato generace na Západě kritizovala vládnoucí západní režimy a protestovala proti systému, vládě či státu. Lidé se často aktivně angažovali v nejrůznějších hnutích namířených proti tehdejším západním státním strukturám. Aron je popisován jako osamělý morální filosof, který stál osaměle proti ideologiím (Baverez 1993).

Tento postoj zastával již v letech 1930-1932, kdy studoval v Německu v Kolíně nad Rýnem a v Berlíně. Během svého pobytu tak na vlastní kůži zažil, co to znamená, když politika začne využívat ideologické myšlení a zmanipuluje masy lidí, kdy racionalita ustupuje emocím. Poprvé zde zažil i přímý antisemitismus, který se stal obecně přijímaným názorem většiny Němců. Tyto jeho zkušenosti byly pro jeho pozdější myšlení zásadní. V Německu té doby si Aron pečlivě všímal motivů, které vedly široké masy občanů k tomu, že požadovali dobrovolně nastolení nedemokratického a nesvobodného režimu. Do své studijní návštěvy v Německu byly pro něj judaismus nebo antisemitismus jen abstraktními pojmy, se kterým se setkal jen při četbě o Dreyfusove aféře či v dětství, kdy na něj spolužáci občas zavolali hanlivé youpin (v dobové francouzštině „židáček“). Jen málokterý intelektuál si tehdy ve Francii uvědomoval nebezpečí antisemitismu, který přichází z Německa. Aron prošel důležitou zkušeností, pochopil a zažil, jak postupně vzniká určitý typ ideologického myšlení. Zároveň byl postaven před etickou otázku: Jak proti takovému 
nebezpečí bojovat? Jak ukázat lidem hrozby určitého typu myšlení? Jeho zkušenost z Německa přispěla k tomu, že se jako profesor, později i jako novinář snažil učit studenty kritickému myšlení založenému na racionální analýze oproštěné od emocí. Když se takto fakta prezentují v pochopitelných, byt na první pohled v skrytých souvislostech, lze odhadnout i vývoj politických rozhodnutí. Ukazoval, že pokud převáží ideologické myšlení, vede vývoj k totalitě a velmi pravděpodobně k válce (např. Aron 1993d; 1993c).

Díky pochopení možného vývoje na základě historického rozboru se dokázal oprostit od předsudků a dokazoval rozpory mezi teoretickou argumentací a konkrétními fakty, které taková argumentace zastírala. Odhaloval tak populistické či ideologické názory, ukazoval realitu takovou, jaká je, nikoliv takovou, jaká se jeví být. Často se připomíná srovnání s jeho spolužákem Jean-Paulem Sartrem, který měl také možnost být ve stejné době v Německu, ale celý svůj pobyt věnoval studiu teorie filosofie vědomí a nevnímal měnící se myšlení německé společnosti. Naopak Aron studoval německé sociology a jejich metody popisu společnosti a jejího vývoje (novokantovce, Maxe Webera). Vnímal nebezpečí aktuálních hrozeb fašistické diktatury, všímal si nerespektování státních institucí, zákonů či vytváření nedemokratických polovojenských skupin, názorů, které jsou tolerantní k veřejně šířeným antisemitským postojům či vytváření kultu osobnosti vůdce (Aron 1935; 1938a).

Po návratu do Francie vnímal Aron politiku obežretněji a citlivěji než valná většina jeho současníků. Francouzská židovská menšina i díky zkušenostem z první světové války vnímala svoji úlohu v postupném začleňování do většinové společnosti. Potomci francouzských Židů si neuvědomovali nebezpečí nacismu a nárůstu antisemitismu v Evropě. Nebezpečí fašistické ideologie se snažilo jeho okolí zlehčovat, což Aron kritizoval. Jeho dcera tuto atmosféru později ilustrovala na náladách obecně židovské komunity ve Francii té doby (Schnapper 1980).

Fašismus byl v Německu podporován širokou veřejností, která si před nástupem Hitlera k moci neuvědomovala katastrofické důsledky takové podpory. Aron ještě před nástupem Hitlera k moci kritizoval fašismus jako hnutí řídící se autoritativní doktrínou bez mechanismů na ochranu plurality názorů, a tedy hnutí, jehož cílem je výbojná politika, jejímž přirozeným vyústěním je válka. Po návratu do Francie psal politické články poukazující na hrozby německého nacionálního socialismu. Jedním z totalitárních důsledků byl antisemitismus, tzn. přirozená forma, jak uměle vytvořit domnělého „vnitřního nepřítele“, proti němuž je třeba se zradikalizovat (viz Aron 1993b). Odezva na Aronovy články ale v atmosféře hospodářské krize ve Francii nebyla výrazná. Jeho argumenty byly zlehčovány, byl obviňován z antigermánských názorů a postojů. (Colquhoun 1986: 90; Furet 1985).

V době nástupu levicové Blumovy vlády ve Francii v roce 1936 byl kritický i k levicovým ideálům. Většina levicových intelektuálů a politiků v té době si realitu podle něj upravila podle toho, jak by chtěli, aby vypadala, nikoliv podle toho, jaká je. Fašismus a komunismus v jeho očích byly weberovským „ideálním typem " ideologického politického myšlení. Odtud se také odvíjel Aronův zájem o studium totalitárních režimů. Totalitarismus používal k interpretaci vývoje uměle vymyšlené zákonitosti, které nekorespondovaly s historickou pravdou. Zabýval se proto filosofií dějin takovým způsobem, aby skrze obecnou teorii mohl vysvětlit 
chyby a záludnosti dezinterpretace historie, kterou totalitarismus často využíval a využívá (Aron 1938a; 1938b; Baverez 1986).

Kritika ideologií, postavení židovské menšiny a nástup totalitarismu vedly Arona k odmítnutí zjednodušeného hegeliánského principu historického vývoje - at v podobě Spenglerových dobově populárních myšlenek o úpadku Evropy, nebo v podobě darwinovských názorů na vývoj společnosti. Soustředil se na práci s konkrétními historickými událostmi, které mohly mít v závislosti na prostředí, čase, aktérech nebo jiných vlivech různé př́ičiny a důsledky. Univerzální zákony lidského vývoje, jak jej prezentoval fašismus a komunismus, zásadně odmítal. Jeho metodou byla logická analýza aktuální politiky. Proto i v okamžiku nástupu nacismu rozpoznal „existencionalisticky“ novou politickou a kulturní situaci, která byla svým nebezpečím zcela odlišná od podobných situací v historii. Po vzoru novokantovců odmítal zavádění metod exaktních věd do věd humanitních. Aron po návratu z Německa do Francie s nedůvěrou sledoval francouzskou vládní „protikrizovou“ politiku podporovanou širokou veřejností s dobovými hesly typu „chléb a svoboda“, kterou prováděla socialistická vláda Lidové fronty. K překonání hospodářské krize využila tato vláda podle Arona populistických kroků, včetně neutrálního postoje k nacismu, kterým předznamenávala i postoj části francouzské veřejnosti k židovské menšině ve Francii (Aron 2003a: 132). Tento vstřícný postoj otvíral prostor, kde se v každé době dobře daří politickým ideologiím (Bredin 1983).

Aron filosoficky chápal jako nejvýraznější rys myšlení racionalismus. A byl to právě racionalismus a úcta $\mathrm{k}$ francouzskému státu, které byly hlavní atributy postupné židovské emancipace. Židé byli zastánci republikánského zřízení, které stálo na přísném oddělení politiky a náboženství. Díky tomu se jejich potomci často propracovali $\mathrm{k}$ vysokým administrativním postům v republikánském zřízení. Antisemitismus se ve Francii po Dreyfusově aféře projevoval s menší otevřeností, ale o to více latentně, kdy se projevy omezovaly na pokřiky typu fous de la République (čes. blázni republiky), protože Židé měli už od Napoleona I. otevřenou možnost kariérního růstu v rámci francouzské republiky, což v plné míře využívali (Birnbaum 1992). I Aron pocházel z takového prostředí, kde Židé začali působit i na univerzitní půdě, jako byli např. Marcel Mauss či Emile Durkheim, kteří získali i prestižní posty v rámci francouzského univerzitního systému (Baverez 1993: 2426).

Spojení racionálního pohledu na politiku a tolerance $\mathrm{k}$ židovské tradici je stěžejní rys Aronova postoje k antisemitismu a Izraeli. Aronovi bylo bližší židovské náboženství jako dialog, jako neustálá diskuze o smyslu náboženství a jeho historii, jak mu $\mathrm{v}$ dopise napsal i jeho přítel a autor řady knih o historii judaismu ve Francii Léon Poliakov. Jediným dogmatem v judaismu, které Aron uznával, byl jeho antidogmatismus (blíže viz Poliakov 1961; Baverez 1993: 34).

\section{ARON A JUdAismus}

Když Aron hodnotil na sklonku svého života vztah k židovství, dospěl ke zjištění, že si nějaký vztah k judaismu začal přímo uvědomovat až s příchodem nacionálního socialismu v Německu (Aron 2003: 50-80). Aron pocházel z rodiny, kdy oba rodiče 
měli židovský původ - jak otec Gustave, tak jeho matka Suzanne Levy. Nicméně celá rodina, jak Aron často říkal, byla „dejudaizovaná“. Aronův nevlastní strýc Robert Anchel popsal v té době historii židovských komunit ve Francii, které měly být nejvíce integrované a dejudaizované v celé Evropě (viz Anchel 1928).

Příslušníci komunity nesvětili doma židovské svátky, nechodili do synagogy ani nemluvili hebrejsky. Aron sám nechodil v mládí do synagogy, první hlubší kontakt s nějakým náboženstvím měl až na střední škole, kde žáci museli chodit do katolického kostela. Proto nikdy nebyl ovlivněn náboženskými představami, at̉ už křestanskými či židovskými. Aronův vztah k náboženství a celému judaismu byl formován racionalitou s odstupem od dodržování tradic a zvyků, které chápal jako nutný prvek sociální integrace. Aron nebyl věřícím člověkem, ale uznával náboženské morální hodnoty, které jsou univerzální v každém náboženství. Obecně náboženství chápal jen jako součást určité kultury. Na judaismu jej více zajímal historický vývoj židovských komunit než nábožensky zabarvené představy o „vyvoleném národě“ (Colquhoun 1986: 14).

Svůj postoj k judaismu vyjadřoval často tím, že se označoval za „Francouze s židovským původem a tradicí“. Když psal v době vzniku Izraele o židovských občanech, používal k označení „židé“ národa malé „ž“ na začátku slova (fr. juifs). Sám sebe označil za francouzského dejudaizovaného občana (fr. déjudaïsé), nebo za asimilovaného žida (fr. juif assimilé). Příslušníky židovské komunity ve Francii označoval za francouzské občany „hlásící se ke stejné náboženské tradici“ (fr. coreligionnaires) (viz Aron 2003b: 243).

Pokud Aron hovořil o svém dětství a židovství, tak mluvil o tom, že pocházel z třídy střední buržoazní židovské francouzské rodiny (fr. bourgeoisie moyenne du judaïsme français). Náboženství a judaismus v jeho rodině nehrálo takovou roli jako fakt, z jakých sociálních poměrů pocházel, tedy z vyšší střední třídy. Studoval na francouzských školách s francouzskými spolužáky a otázkami judaismu a židovství se Aron v té době nezabýval. Věnoval se otázkám filosofie dějin a metodologickým problémům historie a sociologie. Jeho myšlení lze symbolicky označit za příklad „semitského kritického myšlení“ (Fessard 1980).

Proto jeho pozdější vztah k Izraeli ovlivňovalo více faktorů. Nejvýznamnější souvislostí byla jeho vnímavost $\mathrm{k}$ složitosti pochopení židovských tradic. Židé totiž v minulosti trpěli pod tlakem vlastních náboženských předpisů, stejně jako nevraživostí většinové společnosti. Židovské společenství s celou svojí historií bylo pro něj sice citlivým tématem, které se později odráželo i v hodnocení státu Izrael, ale nikdy natolik, aby limitovalo racionální uvažování. Pro pochopení Aronova vztahu $\mathrm{k}$ judaismu můžeme prezentovat diskuzi s francouzským filosofem Jean-Paulem Sartrem (spolužák Arona z École Normale Supérieure de Paris), který chápal židovství v rámci svého existencialistického názoru ,jen “ jako výraz vnějších okolností. Židovství bylo podle Sartra spíše sociálním prvkem většinové společnosti, která se skládá ze sociálních minorit. Minorita tak vytváří tlak na většinu a jde jen o dialektický vztah dvou skupin. Sartre vnímal židovství jako sociální kategorii. Podle Sartra je židovství jen výrazem existenciálního rozhodnutí, když se jedinec rozhodne, jako potomek židovských předků, zda bude, či nebude pokračovat v židovské tradici (Sartre 1954). 
Aron tomuto postoji vytýkal, že Sartre nepochopil, že judaismus je daleko širší problematika, kterou nelze chápat jen sociálně bez znalosti historie a filosofie. Judaismus považoval za kulturní fenomén, který jedince přesahuje. Podle Arona Sartre nedocenil úlohu židovské komunity, ani sociální hloubky židovského náboženství či židovské tradice, ale ani postavení těch židovských potomků, kteří ctili židovské tradice, hlásili se k židovství, zůstali však francouzskými občany (Aron 1989: 21-33; Plottel 1997: 119-129).

Aron vnímal fakt, že židovství a judaismus jsou složité typy určité identity zasahující jak náboženskou, tak národnostní dimenzi, a věrný weberovské typologizaci členil obyvatele vyznávající judaismus na 4 skupiny:

1. Aron vnímal fakt, že židovství a judaismus jsou složité typy určité identity zasahující jak náboženskou, tak národnostní dimenzi, a věrný weberovské typologizaci členil obyvatele vyznávající judaismus na 4 skupiny:

2. ty, kteří v tradici smlouvy mezi Bohem a vyvoleným národem nevěří, ale dodržují tradice tak, aby chránili svoji identitu;

3. ty, kteří asimilovali ve společnosti, ve které žijí, a kteří se odpoutali od židovské komunity, neznají židovskou tradici;

4. ty, kteří se stali izraelskými občany, tj. věřící i nevěřící (podrobněji viz Aron 1972: 161-168).

Sám Aron se vnímal jako člen třetí skupiny. To potvrdil i tím, že jeho manželka Suzanne Gouchon nebyla židovského původu. Svoje pojetí židovství často srovnával s filosofem židovského původu Baruchem Spinozou, který vnímal judaismus jako jeden ze způsobů sociálního sdružování lidí, ve kterém není nic náboženského, ale jde o společenskou komunitu spřízněnou určitou specifickou tradicí (Spinoza 1922).

$\mathrm{K}$ tématu judaismu se Aron vracel častěji v pozdním věku. Na otázku, co pro něj znamená ,judaismus“, odpovídal, že sám přesně neví. Ř́íkával, že je to závazek, jak vyjádřit soucítění s ostatními židovskými občany. Judaismus podle něj nedává volnost myšlení, protože jako jiná náboženství vyžadují od svých věřících dodržování předpisů založených na určitých dogmatech. Aron jako racionální filosof nemohl taková dogmata (i když často založená na vysokých mravních principech) přijmout (Aron cit. in Baverez 1993: 386-389). Za specifikum „židovského národa“ Aron považoval fakt, že lidé uvnitř judaismu žili podle jiných sociálních pravidel než většina a náboženské zvyky vydělovaly z majoritní společnosti, i když předky měly všechny komunity promíšené (Poliakov 1956: 51).

Podle Arona se pohled na židovské komunity změnil až se vznikem státu Izrael, kdy Židé měli poprvé možnost vytvořit vlastní národní stát v intencích národních požadavků 19. století. Z Židů se tak opožděně stal od roku 1948 národ s vlastním státem se všemi problémy, které s sebou existence takového státu nese. Židy lze tak chápat podle Arona sice nábožensky podle judaismu, ale hlavně národnostně podle příslušnosti k státu Izrael. Pokud někdo židovského původu zůstal francouzským občanem, který žije ve Francii, tak by měl sebe sama vnímat především jako Francouze, a nikoliv jako židovského věřícího loajálního více Izraeli než Francii. Podle Arona občanství nelze dělit, občanství je základem státní př́íslušnosti, hájení 
zájmů státu, jehož jsem občanem, je nadřazené náboženskému přesvědčení. Tradice a kultura judaismu je ve svobodném demokratickém státě zaručena skrze občanství a př́íslušnosti k takovému státu. V Aronových očích je tak občanství nadřazené náboženství. Aron polemizoval s myšlenkami, které používají judaismus i křestanství v tom, že existuje nějaký cíl lidského vývoje, a tento cíl je dán nějakou vyšší entitou a je věčný. Podle Arona cíle a smysl určuje jen člověk, politika odhaluje smysl lidského počínání hlouběji než jednání pod vlivem náboženských představ (Aron $1956 \mathrm{~b})$.

\section{Vztah Judaismu a izRaelské politiky V 50. A 60. LeteCh 20 StOletí}

Aron zastával tezi, že židovský stát není pokračovatelem biblického židovského království, jak by jej rády prezentovaly některé židovské politické kruhy. Kritizoval tyto „ideologické“ názory, které nepracovaly s historickými fakty a nesly v sobě stopy prosazování uměle vytvořených dějinných zákonitostí. Aron tvrdil, že existence Izraele je podmíněna politickou situací 20. století. Jak judaismus, tak stát Izrael podléhal v jeho názorech vývoji a okolním společenským podmínkám. Aron odmítal úvahy o biblické determinaci vyvoleného národa. Z politického pohledu se díval na existenci státu Izraele bez předsudků. Podle Arona lze kritizovat jednotlivé politické kroky Izraele, aniž by to mohl někdo nazývat antisemitismem (Aron 1989: 143-163).

Z pohledu Arona bylo možno pro pochopení judaismu porozumět důvodům, proč vznikl židovský stát a také porozumět politickým principům, které v tomto státě fungují. Historie judaismu ukazuje, že neexistuje žádná nutnost či povinnost, aby se Židé stali občany židovského státního útvaru. Stát Izrael je státem, který podléhá stejným zákonitostem a problémům, se kterými se potýkají i ostatní státy. V sekulárním demokratickém státě si každý občan může vyznávat jakékoliv náboženství. Občan se řídí zákony a vykonává vojenskou službu jen jednoho státu. Nemůže se řídit zároveň pravidly jiného státu, kde většinová populace vyznává stejnou víru jako on. Toto pravidlo nadřazenosti jednoho právního řádu nad občanem by mělo platit jak pro Francii, tak i pro Izrael. I přes svoje sympatie k existenci Izraele nelze upřednostňovat zájmy Izraele před zájmy země, jejímž občanem je. Aby státy v konkurenci mezinárodního prostředí fungovaly, musejí se z podstaty chovat v určitém ohledu „egoisticky“. I během první světové války stáli proti sobě občané židovského vyznání na francouzské a německé straně. Sionismus nebyl podle Arona náboženskou záležitostí, ale záležitostí politickou, jenž využíval idejí národního státu. Zakladatelé sionismu věřili více myšlenkám národního státu než židovskému Bohu, který věřícím zaslíbil nějaké území. Jejich úsilí nepodněcovala představa, že postaví nový Chrám, ale že založí vlastní židovský stát. Aron chápal sionismus jako důsledek politického nacionalismu 19. století (Aron 1968: 166).

Základní otázka židovství podle Arona zněla, zda se jednalo o komunitu etnickou, kulturní, náboženskou nebo národní. Etnický judaismus podle něj platil jen pro část židovských věřících (a to se všemi problémy historických konverzí), či pro komunity v Indii, Číně či Etiopii, které se hlásily k židovskému odkazu. Kulturní judaismus byl podle Arona ovlivněný kulturou, ve které tyto komunity žily, s ohledem na specifičnost svého náboženství. Náboženský judaismus byl dle Arona 
jen kulturním kontextem, kdy neexistence jednotné církve či náboženské správy vytvořila zvyky v náboženských úkonech rozdílné od kultur, kde Židé žili. To, co vedlo ke vzniku Izraele podle Arona, bylo národní cítění komunity. Tento motiv podle něj stál u zrodu Izraele, který tvořil hlavní proud judaismu. Díky národní příslušnosti tyto komunity mohly přežít se svojí originalitou. Aron proto ostře polemizoval s tezemi Arnolda Toynbeeho o kontinuálním pokračování židovského národa z biblických dob (Toynbee 1961: 483).

Židé v diaspoře po zboření Druhého chrámu se odvolávali na své semitské kořeny a podle Arona jim náboženství sloužilo jako mytologie. Protože židovské komunity nebyly náboženstvím ani tradicemi asimilovány s většinou, tak tento nedostatek sublimoval v utváření představ o sobě samých. Podle Arona v historii judaismu nebylo nic mysteriózního, nic božského. Náboženské předpisy se staly kulturními vzorci chování a židovské náboženství se tak stalo i židovskou kulturou. Nicméně podle Arona podstatou tohoto chování byla touha po vlastním státě a jednotném národě. Se vznikem Izraele našla tato touha svoji realizaci. Rozdíl mezi náboženstvím a národním cítěním se projevovala v Izraeli té doby, kde byla přítomna neustálá debata o charakteru judaismu uvnitř státu. Pro ultraortodoxní židovské věřící nebyla existence sekulárního státu Izrael podstatná, někteří z nich byli dokonce proti samotné existenci Izraele. Odmítali judaismus na národnostním základě. Jiný postoj zastávali Židé, ke kterým se hlásil i Aron, tedy ti, kteří nepřesídlili do Izraele a zůstali občany původních států. Tvrdil, že odvolávat se na božskou vůli tohoto politického požadavku vede $\mathrm{k}$ idolatrii.

Nejvíce se s otázkou židovství Aron vyrovnával s ohledem na evropský antisemitismus, ale i anti-antisemitismus. Argumenty pracující s kritikou antisemitismu mají být podloženy racionálním základem, nikoliv emocemi. Podle Arona existoval, existuje a bude existovat antisemitismus, jehož zdrojem je akceptování ideologického iracionálního typu myšlení. Každý projev antisemitismu se však vztahuje k nějaké konkrétní historické situaci. Na druhé straně jako projev antisemitismu nelze popisovat každou konstruktivní kritiku židovských komunit. To byl dle Arona problém izraelských politiků, kteří často vnímali kritiku své politiky jako antisemitismus. Jako mezi Francouzi, Němci či Američany existují předsudky a probíhá mezi nimi vzájemná kritika, tak přesto se navzájem nenazývají rasisty (Aron 1972; 1989: 267-280).

Aron rozděloval antisemitismus na více druhů. Jednak náboženský, původně křestaanský (podle Arona tento předsudek související s ukřižováním Ježíše byl původním zdrojem celého antisemitismu), jednak nový antisemitismus spojený s bojem arabského světa proti Izraeli. Tento antisemitismus je zcela jiného charakteru a podléhá aktuálním emocím (např. v 19. století židé arabské obyvatele nazývali jako bratry na koni, v Evropě se stavěly v orientální architektuře synagogy). Potom existuje antisemitismus politický, který Židům nechtěl přiznat plná politická práva jako ostatním národům a souvisel s ekonomickými zájmy (získání jejich majetku). A v neposlední řadě antisemitismus emocionální, který neměl konkrétní př́íčinu, ale obviňoval Židy celkově kvůli jejich odlišnosti co do tradic a zvyků. Německý nacionální socialismus svou biologickou filosofií o střetu ras stvořil kombinaci všech tří kategorií. Nicméně i přes antisemitismus, který ho donutil utéci z okupované Francie, Aron tvrdil, že i tzv. anti-antisemitismus se může stát ideo- 
logickým nástrojem, který útočí proti kritikům izraelské politiky. Sám psal, že se nikdy nestane členem nějaké militantní anti-antisemitské organizace (Aron 1968: 156-157; Colquhoun 1986: 317-318).

Aron tvrdil, že židovská komunita je skupinou, kde se nachází nejrůznější typy lidí. Protože majoritní společnost vždy nálepkuje nějakým zpơsobem minority, tak i Židé byli v době diaspory nějak nálepkováni. Nebezpečím antisemitismu bylo, že byli Židé vnímáni zjednodušeně jako uzavřená „nepřátelská" skupina, někdy náboženská, někdy etnická a někdy národní. Sám Aron proto používá výraz peuple juif (čes. židovský lid) jako výraz pro Izraelce, tak i pro Židy žijící v diaspoře. Podle něj se židovský národ konstituoval až díky existenci židovského státu Izraele. K modernímu židovskému národu se hlásilo mnoho skupin, které neměly společné předky v Palestině. Byli to asimilovaní věřící v nejrůznějších státech či konvertité. Podle Arona proto nebylo možné jasně definovat, kdo byl či nebyl členem židovského národa. Sám tvrdil, že měl „,více společného s francouzským antisemitou než s Židem z marockého jihu" (Aron 2003a: 260). Ideologické myšlení se odráží v situaci, kdy náboženství nevede dialog s ostatními náboženstvími a drží se dogmat, aby nemuselo obhajovat svoji pozici. Aron akceptoval židovskou tradici, ale nesouhlasil s některými zvyky a tradicemi (např. uzavírání sňatků jen po schválení rabínem), kdy byla smíšená manželství považována za odpadlictví. Pokud by byly uplatňovány takové rigidní náboženské předpisy neustále, vymizel by podle Arona v historii židovského národa „tvořivý neklid“, který považoval za základ jeho úspěchu (Friedmann 1965).

V otázkách náboženství byl Aron ovlivněn skeptickým racionalismem. Boha vnímal v kantovské tradici jako morální záruku existence světa, nikoliv jako nějakou nadpozemskou entitu. Aron považoval náboženství za sociologickou kategorii, přičemž světu dávají smysl a význam lidé, ale zároveň lidé i přes svoji svobodu jsou zavázáni morálními humanistickými zásadami, které definovali morální filosofové jako Immanuel Kant (Aron 1973: 137-164; Aron 1989: 228).

Vznik státu Izrael v roce 1948 Aron nerozebíral nijak detailně s ohledem na vznik studené války a existenci těžiště mezinárodních problémů v rozdělené Evropě či dekolonizačním procesu (viz. Nesiba, Smolík 2017). Postavením Izraele se ve svých pracích nezabýval a zůstává jen velmi málo odkazů k jeho názorům z doby na přelomu čtyřicátých a padesátých let, ani se nezabýval situací v arabských zemích. Aronova první ucelená studie o mezinárodních vztazích Le Grand Schisme, čes. Velké schizma, z roku 1948 popisovala mezinárodní politiku, ale Aron zde nevěnoval Izraeli překvapivě žádnou pozornost (Aron 1948). Ani ve své druhé studii z roku 1951 s názvem Les Guerres en chaîne, čes. Války v řetězech, se tématice Izraele nevěnoval (Aron 1951).

Aronův postoj k židovskému státu se ale postupně měnil, jak Izrael začal být rozhodujícím spojencem Západu na Blízkém východě ve studené válce. V době, kdy mnoho arabských zemí podlehlo komunistické ideologii a přiklonilo se na stranu Sovětského svazu, Izrael hrál pro západní země funkci důležitého spojence. V období od Suezské krize v roce 1956 až po šestidenní válku v roce 1967 se Aron stal velkým obhájcem Izraele jako důležitého spojence západních zemí v boji s Moskvou. Tvrdil, že díky válkám s arabskými sousedy a napětí, ve kterém Izrael 
musí působit, je jeho existence určitým zázrakem. Izrael se zrodil na ostří nože a na takovém ostří se naučil žít (Aron 1968: 176).

Aron nenapsal žádnou práci, která by se explicitně zabývala Blízkým východem a jeho historií či politikou Izraele. Nicméně tematika politiky Izraele prostupovala celým jeho dílem, a to i v úvahách, ve kterých analyzoval fungování industriální společnosti s př́lklady z izraelské současnosti (Aron 1962a: 5-26). Analyzoval pomocí weberovských metod demokratické západní liberální společnosti (kam počítal i Izrael) ve srovnání se společnostmi komunistickými (kam řadil arabské státy, které pod vlivem politiky Moskvy intrikovaly proti Izraeli) (Aron 1961; 1974; 1993a; 1994). Atypický politický systém v Izraeli mu sloužil jako častý příklad fungování demokracie. Aron viděl, že i přes snahu otců zakladatelů sionismu identifikovat židovství výhradně s národnostní sekulární myšlenkou, byl stát Izrael svázán s židovskými náboženskými tradicemi, které odporují demokratickému právnímu systému. Jedním z nejvýraznějších specifik izraelské demokracie po vzniku Izraele byla existence tzv. statusu quo. Tedy vztahu mezi státem a náboženstvím. To znamenalo, že z doby před vznikem státu bylo ponecháno respektování některých náboženských pravidel, aniž by byla legislativně zakotvena. Vztah většiny k menšině považoval za jeden z nejpřesnějších indikátorů svobody a demokracie ve zkoumaných zemích (Aron 1959; 1963: 398-401).

Aron byl obhájcem liberalismu jako jediného legitimního prostředku proti totalitárnímu myšlení přicházející v podobě marxistického ideologického proroctví (fr. prophétisme). Toto ideologické myšlení podle Arona pod vlivem Sovětského svazu ovlivňovalo arabské státy bojující od roku 1948 proti existenci Izraele. Aron v obhajobě liberálních evropských hodnot tvrdil, že Marx se ve svém Komunistickém manifestu mýlil, když prohlašoval, že Evropou obchází strašidlo komunismu, protože podle Arona celé poválečné dějiny platí, že Evropou obchází strašidla dvě - a to nejen Rudá armáda ale i vlastní svoboda. Proto v Izraeli odhodlanost boje za svobodu by měla Západu sloužit jako př́íklad (Aron 1977: 459-483).

Téma demokratického prostředí a liberálních hodnot bylo důležité právě s ohledem na srovnání charakteru Izraele a ostatních arabských států Blízkého východu. Aron vyjádřil myšlenku, že liberální hodnoty Izraele jsou ostrůvkem západního typu demokracie uprostřed arabského světa, který zatím neprodělal fázi industriálního vývoje a nedospěl k demokratickému systému vlády. Podle Arona rozvíjející se arabské země kvůli nedemokratickému charakteru vlády důvěřují prorockým vizím o lepším a štastnějším životě, pokud se jim podaří stát Izrael zničit. Tuto jejich ničím neodůvodněnou ideu podporoval účelně Sovětský svaz. Proto i náboženský judaismus vnímal jako určité nebezpečí pro demokracii. Demokratický základ státu dával podle Arona Izraeli právo na existenci (Aron 1972; 1989: 67).

Arabské státy byly velmi často ovlivněny hodnotami importovanými zvnějšku (národnostní boj, komunistická ideologie), které ale nebyly slučitelné s tradicí evropské demokracie a liberalismu, jak je vyznával a obhajoval Aron (Chanlat 1982: 119-132).

Arabské státy považovaly demokratické hodnoty jako západní imperialistické mocenské nástroje, kterými bývalí kolonizátoři chtějí rozložit tradiční arabskou společnost, a proto je odmítaly. V padesátých a šedesátých letech platil tento rozpor podle Arona pro Izrael a jeho sousedy v Egyptě či Sýrii. V těchto zemích se neustále 
střídaly u moci extrémní politické síly (levicové či pravicové) a řešením podle Arona bylo přijetí demokracie a liberalismu, aby tyto státy nebyly závislé stále na vnějších ideologiích (Aron 1977: 143).

Podle Arona během studené války probíhal boj mezi demokratickým světem a světem ideologií, mezi západními demokratickými hodnotami a totalitárními autoritářskými režimy, mezi tržní a centrálně řízenou ekonomikou. Aron obhajoval demokratické hodnoty Izraele vůči ideologiím prezentovaným nejrůznějšími arabskými režimy. Tento respekt $\mathrm{k}$ demokratickým izraelským hodnotám můžeme nalézt v Aronově zdůraznění, že západní svět je závislý na arabské ropě a celou svojí politikou musí brát ohled na tento ekonomický zájem. Na druhou stranu na izraelských výrobcích není závislý žádný stát (Aron 1977: 294).

Podle Arona v 60. letech řada levicových intelektuálů na Západě vnímala sionismus s předsudkem. Existenci Izraele založeného na základě sionistického hnutí považovali za prodloužení imperialistické politiky Washingtonu. Podle Arona byla taková interpretace naivní už v tom ohledu, že stát Izrael dával svým občanům daleko více demokratických svobod, než měli arabští občané v okolních státech. Aron obhajoval stát Izrael jako nositele demokratických hodnot, a proto jeho existenci považoval za oprávněnou. Izrael považoval za významného hráče v době studené války přimknutého $\mathrm{k}$ západním státům. Postupně se stát Izrael stával výhradním spojencem Spojených států amerických, oproti arabským státům podporovaných Sovětským svazem a dle Arona nezbývalo státu Izrael nic jiného než vést obrannou válku (Aron 1976: 199).

Ve všech konfliktech byl Izrael podporován západními zeměmi (nejdřive z Evropy, poté z USA), nicméně toto spojení bylo vždy taktické a strategické, nikoliv ideologické. Izrael využíval západní podpory na eliminování sovětské síly poskytnuté arabským zemím, které usilovaly o jeho zničení. Arabské země využívaly zjednodušené rétoriky o utlačovaných a utlačovatelích. Za utlačovatele byli označováni Britové a Židé, protože vznik britského mandátního území byl dle jejich argumentace součástí kapitalistické imperialistické politiky. Vznik státu Izrael byl potom prezentován jako pokračování této imperialistické politiky. Britům bylo dáváno za vinu, že odchod britských vojsk způsobil konflikt v této oblasti. Podle Arona byla takto zjednodušeně interpretovaná historie nepř́ípustná, už jen z faktu, že Britové a židovští imigranti v Izraeli proti sobě tvrdě bojovali. Rétorika prezentující realitu na „dobré“ a „zlé" nalezla podle Arona odezvu mezi oportunistickými politiky. Aron si všímal toho, že konflikt mezi židovským a arabským obyvatelstvem byl založen na rozdílné argumentaci a prosazování zájmů obou skupin, kdy názory typu, že „Židé se vrátili do své domoviny díky holocaustu“ či naopak „Židé dobyli Palestinu ve válce a okupují pomocí agrese palestinské území" jsou ideologiemi. Problémem byl podle Arona fakt, že žádný z těchto argumentů nedokáže nechat nikoho jako neutrálního pozorovatele. Sám Aron se snažil svými analýzami toto černobílé vidění pochopit. Nešlo podle něj jen o momentální politickou situaci, ale i o dlouhodobější perspektivu regionu (Aron 1968: 71). 


\section{ARON A IZRAelská POLITIKA Od ROKU 1967}

Aronův pohled na Izrael prošel proměnou po skončení šestidenní války v roce 1967. Aron izraelský preventivní útok obhajoval. V této kritické situaci se projevila jeho nejhlubší podpora Izraele. Nejvíce byla patrná tato podpora v tom, jak se dokázal Aron postavit proti názorům francouzského prezidenta de Gaulla, který byl jeho přítelem. Prezident vystoupil na tiskové konferenci po zahájení války a velmi ostře proti izraelskému útoku argumentoval. De Gaullův projev se nesl ale i v ostré kritice židovského národa a judaismu jako takového, nikoliv jen v politickém ohledu, ale i v pohledu etnickém. De Gaulle napadl židy jako etnikum a nikoliv politiku státu Izrael. Aron označoval tento přístup de Gaulla za zbytečně antisemitský, kdy de Gaulle podlehl zjednodušení a spojil politiku státu Izrael s židovstvím jako takovým.

Postupně v následující době okupace Golanských výšin a pásma Gazy izraelskou armádou ale Aron vnímal nespravedlnost ze strany Izraele na civilním palestinském obyvatelstvu. Právě v době od 70. let se v jeho úvahách objevuje názor, kdy humanistické ideály judaismu dával do konfrontace s aktuální izraelskou politikou. Aron se pouštěl do polemiky s izraelskou politikou, právě vzhledem k palestinskému problému. Po šestidenní válce nastaly problémy na okupovaných palestinských územích, s radikalizací židovských osadníků, s bojem o Jeruzalém a vzniku terorismu. Podle Arona byly tyto problémy konkrétními dílčími situacemi, nikoliv dlouhodobou strategií, která by měla utvářet mezinárodní vztahy dvou států. Moderní doba zdramatizovala podle Arona boj o zemi a o půdu, jak ukázal dekolonizační proces. Tématu soužití židovského a palestinského národa se Aron intenzivně věnoval od sedmdesátých let. V Izraeli nemohou podle něj vytvořit oba národy jedno společenství a nemohou obývat stejné území - jedni či druzí cítí nespravedlnost (Aron 1973a). Aron v otázkách geografického prostoru - osidlování a boj v Izraeli o samostatné státy Židů a Palestinců nazývá „sázkou“ (fr. enjeu). Je to sázka na to, kdo v budoucnu zvítězí. Každý může mít své zbraně, na jedné straně technologie, na straně druhé demografické faktory a spojenectví okolních států (viz Aron 1980a; 1980b).

Oba národy s právem na vlastní stát rozděluje i náboženství, které podle Arona obecně netvoří příslušnost k národu. Pochopit situaci v Izraeli bylo pro Arona založeno na pochopení obou náboženství - muslimského a židovského. Aron tak od 70. let projevoval překvapení, že se náboženství stalo novým dogmatem a obě strany konfliktu jej začaly využívat pro boj se soupeřem. Jak od sedmdesátých let začaly teroristické útoky palestinských radikálů, byly zataženy do konfliktu i židovské komunity na celém světě, které ale nemusely s aktuální politikou Izraelem mít společné zájmy. Aron sledoval po šestidenní válce, jak roste náboženský dogmatismus a militarismus. Státní politika v Izraeli se podřídila zájmům náboženství. Náboženský stát podle Arona nebylo možné uskutečnit v multinárodnostním a multináboženském prostředí. Aron požadoval, aby stát byl převážně laický, nikoliv náboženský (Aron 1962a: 375).

Od sedmdesátých let Aron začal popisovat jiný Izrael. Sám se zaměřoval na univerzální hodnoty státu Izrael, které se mají projevovat v politickém stylu. Pokud měla být politika demokratická, měla by obsahovat i demokratické prin- 
cipy a aspekty, které ji umožňují (kulturní a sociální vzestup). Národnostní idea tak podle Arona v sobě má nést občanství v demokratickém slova smyslu a zároveň samostatnost bez cizích vládců, s jasnými hranicemi státu (Aron 1981: 113-121; 1989: 239).

Podle Arona byla národnostní idea derivací politiky. Národní idea podle něj nebyla univerzální ideou, vždy záleží na podmínkách, za kterých vzniká národnostní stát. Pojem národního státu považoval Aron za určitý vzor, který se ale mění podle podmínek v čase a prostoru. Právě státní suverenita byla jedním ze zpo̊sobů, jak etnicky sjednotit národ. Konkrétní státní politika a národní ideje jsou podle Arona spojité nádoby. Každý stát svou politikou ukazuje, jak vyspělý národ v něm žije (Aron 1989: 245). Aron mj. kritizoval židovské lobbistické skupiny v USA, které mimo izraelské velvyslanectví zastupují „nepřehledně“ zájmy Izraele v podobě soukromých společností jako např. American Jewish Committee. Na podporu americké židovské diaspory vůči Izraeli se Aron díval zdrženlivě, činilo to samostatnou mezinárodní politiku Izraele velmi labilní (Aron 1989: 251-255).

Aron byl zastáncem etatismu, když přiznával, že s existencí Izraele se pojí mnoho netradičních politických propojení ve vztahu diaspory a židovských obyvatel žijících v Izraeli. V případě teoretického konfliktu mezi Izraelem a nějakým státem by tak podle Arona židovská komunita žijící v tomto státě měla podporovat stát, jehož národnost má. Princip dvojího občanství podle Arona nebyl dobrou cestou k průhledným mezinárodním vztahům. Z historie židovských komunit ve Francii v moderní době, tak jak je studoval Aron, vyplynulo, že asimilovaní Židé vždy hájili zájmy Francie. Po vzniku Izraele Aron proto nerozuměl těm novým židovským kruhům ve Francii, které preferovaly zájmy Izraele před Francií, aniž by využily možnosti se do Izraele vystěhovat a užívají francouzské občanství (Harris, Sédouy 1977; Feuerwerker 1976; Blumenkranz 1972).

Aron tak definoval svůj vztah k Izraeli jako intelektuálnější a více organický. Byl to projev jeho solidarity jako existenciálního př́ístupu. Na otázku, jaké místo hrál v jeho životě Izrael, odpověděl v pozdním věku Aron v tom smyslu, že si takovou otázku nepokládá jen tak každý den. Byla to otázka, na kterou pravděpodobně nedokázal odpovědět vždy stejně. Nicméně po dlouhých váháních připustil určitou záhadnost jeho vztahu k Izraeli. Pokud mluvil o Izraeli, vždy si paradoxně uvědomil, že je francouzským občanem se všemi právy a povinnostmi vyplývající z občanství (Aron 1989: 185-190).

\section{ARONOVA KRITIKA ZNEUŽíVÁNí ANTISEMITISMU}

Aron se stal i pro francouzského prezidenta Valéryho Giscard d'Estaigna neformálním poradcem pro záležitosti vztahující se k francouzsko-izraelským vztahům a býval neformálně označován jako „Juif de cour" (v češ. židovský poradce na dvoře). Tuto pozici si zasloužil hlavně díky tomu, že blízkovýchodní problematice dokonale rozuměl a určoval tak vztah Francie ke státu Izrael (Baverez 1993: 437). Mimo to, skoro osmdesátiletý Aron vydal knihu svých pamětí, které byly kronikou francouzské historie ve 20. století. Aron měl dokonce v úmyslu nazvat své Paměti v první verzi jako „Vzpomínky židovského Francouze“ (fr. Souvenirs d'un français 
juif), a tak demonstrovat na vývoji židovské menšiny historii dvacátého století ve Francii (Baverez 1993: 437; Bredin 1983).

V posledních letech svého života se proto začal intenzivně věnovat problematice antisemitismu a otázkám židovské diaspory v Evropě a Francii (Aron 2009: 106111; 1981: 10-11). Zajímal se o kořeny a př́ičiny ideologického myšlení projevující se v antisemitismu, který na přelomu sedmdesátých a osmdesátých let znovu propukl v souvislosti s konfliktem v Izraeli mezi židovskou a palestinskou populací. Aron znovu analyzoval, co antisemitismus vlastně obnáší. Odmítal stálé paušalizování na „přátele“ a „nepřátele“ Izraele, kteří jsou označování apriorně jako antisemité. Podle Arona tehdejší doby je antisemitismus jako každá ideologie založen na manipulaci s myšlením. Proto by kritikové antisemitismu neměli pracovat s podobným manipulativním zjednodušením historie. Konkrétně se zabýval problematikou kořenů francouzského antisemitismu ve třicátých letech 20. století. Veřejnou debatu na toto téma vyvolal francouzský historik Bernard-Henry Lévy, který tvrdil, že kořeny francouzského fašismu lze rozpoznat už v dílech francouzských klasických spisovatelů. Podle Lévyho byl fašismus součástí francouzské kultury od 19. století. Provokativní kniha vyvolala debatu o míře francouzské kolaborace s nacismem za války (Lévy 1981).

Pro Arona představoval tento typ intelektuální práce, jak předvedl Lévy s dějinami, zjednodušený pohled a subjektivní interpretaci autora, nikoliv pochopení samotné doby. Proto se pustil do veřejné polemiky. Debata se soustředila na charakter vichistického režimu, který Lévy považoval za stejně nacistický a protižidovský, jako byl v Německu (srov. Sternhell 1983). Aron naopak hodnotil vichistickou vládu, která sice umožnila toleranci antisemitismu, jako účelovou. Sice francouzský vichistický stát přispěl k utrpení židovských obyvatel a spolupracoval s německým nacistickým režimem, ale na druhou stranu srovnávání válečného režimu ve Francii a Německu bylo podle Arona zavádějící a demagogické (Fabre-Luce 1978).

Dalším faktem, který svědčil o tom, jakým způsobem se Aron zapojoval do diskuzí o nových formách antisemitismu, byly články Aronových kolegů z magazínu L'Express, kam Aron přispíval svými esejemi poté, co ukončil spolupráci s deníkem Le Figaro (Aron 1994, Aron 2005). Nedlouho po jeho nástupu do tohoto listu zde byl otisknut rozhovor s jistým Louis Darquier de Pellepoixem. Tento muž byl během nacistické okupace Francie zodpovědný za deportace 75 tisíc Židů do koncentračních táborů z Francie. Měl přezdívku „francouzský Eichmann“ (Ganier-Raymond 1978). Po skončení války byl ve Francii odsouzen k smrti, ale podařilo se mu uprchnout a nalezl azyl ve frankistickém Španělsku. Skoro osmdesátiletý Pellepoix byl vystopován novináři z L'Expressu, kteří s ním udělali rozhovor. $\mathrm{V}$ rozhovoru Pellepoix vysvětloval svoji roli ve spolupráci s nacisty a tvrdil, že se snažil udělat podmínky pro deportované co nejvíce snesitelné. Navíc tvrdil, že neměl nic společného s velkými pogromy v Paříži (Aron 1989: 283-286).

Po uveřejnění rozhovoru se strhla ve Francii lavina obvinění z antisemitismu deníku L'Express, z jeho rasismu a neetického chování, až k obvinění z popírání holocaustu a banalizaci nacismu. Aron se postavil na stranu obhajoby novinářské práce, jakou byl i rozhovor s Pellepoixem. Rozhovor totiž nezastíral realitu totalitního režimu. Podle něj pracoval s historickými fakty a ukázal, jak totalitní režimy manipulovaly s jedincem. Aron ukazoval, jak popírání historických souvislostí může 
deformovat náš obraz o těchto nebezpečích. Ukázal i zcela vychýlený obraz světa u Pellepoixe, který stále věřil v židovský komplot ve světě a popíral holocaust. Aron se zastal práce novináře, který rozhovor dělal, nebot novinář vysvětlil kontext a skutečná historická fakta (Colquhoun 1986: 514).

Tato debata se odehrávala v okamžiku, kdy se ve Francii objevily antisemitské útoky, převážně na židovské synagogy. Z nich nejznámější byl v Rue Copernic v Paříži v ř́ijnu 1980 provedený Palestinci. Někteří intelektuálové ve Francii dávali útoky do souvislosti s předválečným nacistickým antisemitismem. Ale Aron nesouhlasil se zjednodušeným přenesením charakteristicky předválečného antisemitismu do hodnocení moderního antisemitismu. Zastával názor, že tento nový antisemitismus rozmáhající se po vzniku státu Izrael má jiný charakter, protože souvisí s jinou formou násilí a represivní politikou Izraele vůči Palestincům. Palestinské teroristické antisemitské útoky směřovaly i na židovskou diasporu mimo Izrael. Nejednalo se o snahu vyhladit židovský národ jako celek, ale v těchto činech se odrážela podle Arona mezinárodní politika. Nacistická ideologie byla založena na vyhlazení jednoho národa hlásícího se k židovské náboženské a kulturní tradici. Nová forma „arabského" antisemitismu byla založena na boji proti židovskému státu. Nejednalo se o boj proti Židům, ale o boj proti politice státu Izrael (Aron 2003a: 707; 2003b). Aron tak vinu přičítal mezinárodní politice, která díky spolupráci s ropnými arabskými velmocemi neměla zájem na řešení blízkovýchodní otázky (Aron 2005: 293-298).

Aron se s tematikou údajného francouzského antisemitismu a kolaborace střetl na úplném konci svého života, když byl u soudu svědkem sporu mezi Zeev Sternhellem, izraelským historikem, který kritizoval na základě analýzy textů z doby před druhou světovou válkou údajný fašismus francouzského novináře a ekonoma Bertranda de Jouvenela (Sternhell 1978). Shodou okolností byl Bertrand de Jouvenel Aronovým přítelem. Kritika, které ho Sternhell podrobil, se jej vnitřně dotkla. Vyvolal proto soudní přelíčení na ochranu své osobnosti a zažaloval Sternhella za urážku. Aron, který se Sternhellovým „honem na čarodějnice“ a hledáním údajných fašistů mezi francouzskými intelektuály nesouhlasil, svědčil v Jouvenealův prospěch. Zde potvrdil svůj dřívější názor, že za kolaboranta již od dob své exilové práce v Londýně považoval spíše pařižšého intelektuála, který se zajímal o dialektiku a filosofii více než o aktuální dění, nebo funkcionáře a vojenské činitele III. republiky či ideology. Tedy ty, kteří mohli, ale kteří se neangažovali proti zlovůli a tyranii (Aron 1943: 303-309). Několik hodin po svém svědectví Aron 17. ř́ijna 1983 umřel na srdeční příhodu.

\section{ZÁVĚR}

Příspěvek ukazuje vývoj myšlení francouzského sociologa, filosofa a historika Raymonda Arona, který se okrajově ve svém díle dotýkal otázek spojených s židovstvím, a to převážně díky svému židovskému původu. Článek prezentuje na příkladu analýz ideologického myšlení ve vztahu k judaismu, jak byl Aron konzistentním badatelem v sociálních vědách, který racionální analýzu a metodiku popisu tzv. dějin přítomnosti dokázal aplikovat i na emotivně vyhrocená témata (antisemitismus, vztah Izraele a palestinského národa), jejichž popis přitahuje 
zjednodušené vidění typické pro zájmy politické ideologie. Na představeném tématu z jeho obsáhlého díla autoři ukazují, že preferoval nestrannou metodiku popisu historie či politiky, založenou na racionální analýze. Tento přístup je třeba dle Arona aplikovat i přes možný sentiment i či osobní zaujetí pozorovatele v celé oblasti sociálních věd. Příspěvek prezentuje, jak Aron osobním př́ikladem akademické i novinářské práce toto prokázal v analýzách problematiky antisemitismu či izraelské politiky. Sám jako potomek židovské rodiny ve Francii mohl přistupovat k tématům z hlediska hledání viny za antisemitismus, z hlediska popisování křivd na židovském národě. Aron toto nečinil a držel si nadhled a odstup. Preferoval racionální analýzu jako bariéru proti ideologickému zjednodušování historie a politiky. Aron jako kritik ideologií a zastánce demokratické diskuze ukazoval, že demokracie vyžaduje u intelektuála schopnost takového myšlení, které umožňuje odhalovat náznaky ideologického černobílého vidění světa. Ideologie vede v důsledku k ohrožení celé demokracie. Racionalita má vyšší platnost než aktuální sympatie či emoce. Tento jeho př́stup $\mathrm{k}$ popisu historie lze doložit na jeho metodologicky konzistentním myšlení o židovství a Izraeli v průběhu bezmála padesáti let, a to od doby přicházejícího nacismus v Německu a Francii 30. let, a s tím spojeného antisemitismu, tak na politice státu Izrael, který od levicových sionistických myšlenek v 50. letech přešel $\mathrm{k}$ tvrdé pravicové politice v 70. letech 20 století. Aron ukazoval krátkozrakost takové politiky a dokládal, na jaké konflikty se z tohoto důvodu musí Izrael v budoucnu připravit.

\section{BiBLIOGRAFIE}

Anchel, R. 1928. Napoléon et les Juifs. Paris: Presses Universitaires de France.

Aron, R. 1935. La sociologie allemande contemporaine. Paris: Alcan.

Aron, R. 1938a. Essai sur la théorie de l'histoire dans l'Allemagne contemporaine. La philosophie critique de l'histoire. Paris: Vrin.

Aron, R. 1938b. Introduction à la philosophie de l'histoire. Essai sur les limites de l'objectivité historique. Paris: Gallimard.

Aron, R. 1943. „La Chronique de France: Colaboration ou abstention." La France libre 28 (5): 303-309.

Aron, R. 1945. L'Âge des Empires et l'ávenir de la France. Paris: Défense de la France.

Aron, R. 1948. Le Grand Schisme. Paris: Gallimard.

Aron, R. 1951. Les Guerres en chaînes. Paris: Calmann-Lévy.

Aron, R. 1956a. Espoir et peur du si?cle. Essaie non partisans. Paris: Calmann-Lévy, Liberté de l'esprit.

Aron, R. 1956b. „Le fanatisme, la prudence et la foi." Preuves 63: 8-22.

Aron, R. 1959. La Société industrielle et la Guerre, suivi d'un Tableau de la diplomatie mondiale en 1958. Paris: Plon.

Aron, R. (ed.). 1961. L'Histoire et ses interprétations - Entretiens autour de Toyenbee. Paris: Mouton.

Aron, R. 1962a. Paix et guerre entre les nations. Paris: Calmann-Lévy.

Aron, R. 1962b. „A propos de la théorie politique." Revue française de science politique 1 (12): 5-26. 
Aron, R. 1963. Dix-huit leçon sur la société industrielle. Paris: Gallimard.

Aron, R. 1964. La lutte de classes. Paris: Gallimard.

Aron, R. 1968. De Gaulle, Israël et les Juifs. Paris: Plon.

Aron, R. 1971. „Comment l'historien écrit l'épistémologie.“ Annales 26 (6): 1319-1354.

Aron, R. 1972. „Israël et les Juifs de France.“ Disperion et Unité 1972 (2): 160-168.

Aron, R. 1973. „Un philosophe libéral dans l'histoire, Entretien avec Ch. Chabanis.“ Pp 137-164 in Ch. Chabanis (ed.). Dieu existe-t-il? non répondet... Paris: Fayard.

Aron, R. 1974. „Récit, analyse, intepretation, explication: critique de quleques problemes de la connaissance historique." Archives européennes du sociologie 15 (2): 73-105.

Aron, R. 1976. Penser la guerre, Clausewitz. I: L'Âge européen. II: L'Âge planétaire. Paris: Gallimard, Bibliothéque des Science humaines.

Aron, R. 1977. Plaidoyer pour l'Europe decadente. Paris: Robert Laffont.

Aron, R. 1980a. „Interview. “ Le Matin de Paris, 12. 9. 1980, p. 3.

Aron, R. 1980b. „Interview." Le Quotidien de Paris, 10. 9. 1980, p. 2.

Aron, R. 1981. "Communication." in Issues facing World Jewery: Report of the Blue Ribbon Commision of the World Jewery Congress. Washington: Hershel Shanks.

Aron, R. 1989. Essais sur la condition juive contemporaine. Paris: Édition de Fallois.

Aron, R. 1993a. Demokracie a totalitarismus. Brno: Atlantis.

Aron, R. 1993b. „La Révolution nationale en Allemagne.“ Pp 141-154 in Stark J. Raymond Aron: Über Deutschland und den Nationalsozialismus. Opladen: Leske und Budrich.

Aron, R. 1993c. „Réflexions de politique réaliste. Berlin.“ Pp 86-89 in Stark J. Raymond Aron: Über Deutschland und den Nationalsozialismus. Opladen: Leske und Budrich.

Aron, R. 1993d. „Révision de traités: Lettre d'Allemagne.“ Pp 49-51 in Stark J. Raymond Aron: Über Deutschland und den Nationalsozialismus. Opladen: Leske und Budrich.

Aron, R. 1994. Les articles de politique internationale dans Le Figaro de 1947 à 1977, II., La Coexistance (mai 1955 à février 1965). Paris: Édition de Fallois.

Aron, R. 2003a. Mémoires. 50 ans de réflexion politique. Paris: Édition Robert Laffont.

Aron, R. 2003b. Angažovaný pozorovatel. Rozhovory s Jeanem-Louisem Missikou a Dominiquem Woltonem. Praha: Mladá Fronta.

Aron, R. 2005. De Giscard à Mitterrand: 1977-1983. Paris: Fallois.

Aron, R. 2009. „Réflexion actuelles sur la réalité israélienne.“ Dispersion et Unité 2009 (16): 106-111.

Baverez, N. 1986. Raymond Aron. Qui suis-je? Paris: La Manufacture.

Baverez, N. 1993. Raymond Aron. Un moraliste au temps des idéologies. Paris: Flammarion.

Birnbaum, P. 1992. Les Fous de la République, Histoire politique des Juifs d'Etat de Gambetta à Vichy. Paris: Fayard.

Blumenkranz, B. (ed.) 1972. Histoire des Juifs en France. Toulouse: Éditeur Privat.

Bredin, J.-D. 1983. L'Affaire. Paris: Juillard.

Bruckeberger, P. R. 1987. „Notice sur la vie et les travaux de Raymond Aron." [online] Academie des sciences morales et politiques [cit. 7. 3. 2018]. Dostupné z: http: //www.asmp.fr/travaux/notices/aron_bruckberger.htm.

Colquhoun, R. 1986. The Philosopher in History 1905-1983, Volume I, II. London: SAGE Publication.

Dahrendorf, R. 2008. Pokušení nesvobody. Intelektuálové v čase zkoušek. Praha: $\mathrm{H}+\mathrm{H}$. 
Fabre-Luce, A. 1978. Pour en finir avec l'antisemitisme. Paris: Julliard.

Fessard, G. 1980. La philosophie historique de Raymond Aron. Paris: Julliard.

Feuerwerker, D. 1976. L'Émancipation des Juifs en France. De l'Ancien Régime à la fin du Second Empire. Paris: Albin Michel.

Friedmann, G. 1965. Fin du peuple juif? Paris: Gallimard Idées.

Furet, F. (ed.). 1985. L'Allemange nazie et le génocide juif. Colloque de l'École des Hautes Études en sciences sociales. Paris: Gallimard.

Ganier-Raymond, P. 1978. „A Auschwitz, on n'a gazé quo les poux.“ L'Express, 4. 11. 1978, p. 4.

Harris, A., A. Sédouy. 1977. Juifs et Français. Paris: Grasset.

Chanlat, J.-F. 1982. „Raymond Aron: l'itinéraire d'un sociologue libéral." Sociologie et sociétés 14 (2): 119-132.

Leterre, T. 2005. „Aron, Aristocrate de l'intelligence." [online] parutions.com [cit. 5. 3. 2018]. Dostupné z: http://www.parutions.com/index.php?pid=1\&rid=76\&srid=0\&ida= 3408 .

Lévy, B.-H. 1981. L'Idéologie française. Paris: Grasset.

Meuwly, O. 2005. „Raymond Aron: portrait d'un penseur libéral qui échappe aux classifications hâtives." [online] Le Temps [cit. 1. 3. 2018]. Dostupné z: https://www.letemps.ch/ opinions/raymond-aron-portrait-dun-penseur-liberal-echappe-aux-classificationshatives.

Nesiba J., J. Smolík. 2017. „Od obranné války k válce s terorismem. Pohled Raymonda Arona na izraelskou politiku." Kultura bezpieczeňstva 2018 (27): 139-164.

Nesiba, J. 2010. „Hrozba ideologií a totalitarismu v díle Raymonda Arona.“ Auspicia 6 (2): $92-102$.

Plottel, J. P. 1997. „Jewish Identity in Raymond Aron, Emmanuel Berl and Claude LéviStrauss." Pp 119-129 in L. D. Kritzman (ed.). Auschwitz and After. Race, Culture and "the jewish question" in France. London: Routlege.

Poliakov, L. 1956. Histoire de l'antisemitisme. I. Paris: Calmann-Lévy.

Sartre, J.-P. 1954. Réflexions sur la question juive. Paris: Gallimard.

Schnapper, D. 1980. Juifs et Israélites. Paris: Gallimard.

Sirinelli, J.-F. 1995. Sartre et Aron, deux intellectuels dans le siècle. Paris: Hachette Littératures, coll. Pluriel.

Spinoza, B. 1922. Traktát teologicko-politický. Praha: Tribuna.

Sternhell, Z. 1978. La Droite révolutionnaire, les origines françaises du fascisme. Paris: Seuil.

Terray, E. 1986. „Violence et calcul. Raymond Aron lecteur de Clausewitz." Revue française de science politique 6 (2): 48-268.

Toynbee, A. 1961. A Study of History. London \& New York: Oxford University Press.

\section{SUMMARY}

The article discusses the development of the thinking of French sociologist, philosopher and historian Raymond Aron, who touched on questions relating to Judaism, primarily due to his own Jewish background. The paper presents Aron's analysis about ideological thought in relation to Judaism. Aron was a consistent researcher in the social sciences, who applied the rational analysis and methodology of the so-called "history of presence" 
to highly emotional topics (e.g. anti-Semitism, the relationship between the Israeli and the Palestinian nation), which often attract a simplified black-white ideological interpretations. On the subject presented in his extensive work, the authors show that he preferred an impartial methodology of a history and description based on rational analysis. This approach, according to Aron, must be applied despite the potential sentiment or personal attitude of the observer in the whole sphere of the social sciences. Aron stands as a personal example of academic and journalistic work in the analyses of anti-Semitism and Israeli politics. As a descendant of a Jewish family in France, he could approach the themes from the point of view of guilt for anti-Semitism in terms of describing the injustices to the Jewish nation. Aron did not do this, and kept his sight and distance. He preferred rational analysis as a barrier to the ideological simplification of history and politics. Aron, as a critic of ideologies and advocates of democratic debate, has shown that democracy requires intellectuals that reveal the signs of an ideological black-and-white vision of the world that then leads to threats to the whole democracy. Rationality has a higher validity than the current sympathy or emotion. This approach to the history of presence can be substantiated by his methodologically consistent thinking about Judaism and Israel over a period of almost fifty years, from the time of rising Nazism in Germany and France in the 1930s and followed by anti-Semitism to the policy of the State of Israel. Left-wing Zionist ideas in the 1950s moved to hard right-wing politics in the 1970s. Aron showed the short-sightedness of such a policy and demonstrated what conflicts Israel will need to prepare for the future.

Aron refused any form of historicism and determinism (one of the most widely used arguments in the Middle East debate, i.e. who has the right to inhabit the area, Jews or Palestinians) so as not to fall into the trap of naive idealism brought about by black and white value judgments. In his view as a liberal, one is free, but in his actions he is limited by social, political, and economic realities. Knowing these limitations is the task of the historian; knowing the freedom of the individual is the task of the philosopher.

In the context of Aron's familiar attitude toward ideologies, it is often neglected that he himself came from a Jewish assimilated family. That is why he took notice of the antiSemitic moods in France and in Germany. In the paper, we investigate how Aron dealt in his work with his family background and how it affected him in sociological analysis modern society and international relations, especially with regard to Israeli politics. Aron's attitude to this issue has changed. In the 1950s, he manifested a distrust of Zionism as a leftist movement, then expressed solidarity with Israel's defensive war in the 1960s, and at the end of his life as a journalist criticized the style of right-wing Israeli policy. Aron's views on this subject oscillated between an impartial sociological scientific approach to exploring religion as a part of social ties in society along with sentiments about Judaism and democratic principles in Israel. This, however, did not resign him to a rational and impartial analysis, and he can be distinguished from the ideology inherent in Judaism and Israeli politics. Aron's talent for the philosophical evaluation of historical and topical political issues was applied with a consistent emphasis on working with facts rather than reflection. The article is about introducing the dynamics of Aron's thinking as well as showing how to maintain a rational methodology of analysis for emotional issues. 